\title{
Financialization and Inequalities in Income and Wealth
}

\author{
Valeed Ahmad Ansari \\ Aligarh Muslim University, India
}

\begin{abstract}
The inequality issue has become a central concern for the majority of economists. Financialization is, among others, a major cause of inequalities in income and wealth. This paper examines opinions of some noted scholars on this issue. In reality, the financial sector has moved away from its basic function of allocating capital to productive uses, to those activities which do not create wealth rather, they transfer it from others to finance manipulators. Financialization leads to the development of new financial products that are several layers away from the real economy. The oversized financial sector has strayed away from its essential function. Several empirical studies document that "too much finance" may hamper growth, create distortions, and contribute to income inequality.
\end{abstract}

Keywords: Financialization, Financial innovation, Growth of debt, Inequality, Poverty alleviation, Shareholder value maximization.

KAUJIE Classification: N2, N3, N4, N7.

\section{Introduction}

The mounting evidence of inequalities of income and wealth across the world has fueled a heated debate (Piketty, 2013; Oxfam International, 2017). In his remarks while releasing the OECD 2015 report, Angel Gurría observed that "We have reached a tipping point. Inequality can no longer be treated as an afterthought. We need to focus the debate on how the benefits of growth are distributed". President Obama, in his departing speech delivered to the UN General Assembly in September 2016, stated: "A world in which $1 \%$ of humanity controls as much wealth as the other $99 \%$ will never be stable" (White House Archived, 2016). The World Bank's inaugural report on poverty and shared prosperity (World
Bank, 2016, p. 2) points out that inequality within countries is higher than what it was 25 years ago, and asserts that reductions in inequality will be key to eradicate poverty to attain the Sustainable Development goal by 2030. Further, it states "[Inequality] is also an issue of fairness and justice that resonates across societies on its own merits" (p. 2). However, it would be of interest to note that the inequality issue was not favorably viewed by some economists. In this context, the remark of Nobel laureate Lucas is worth noting. Lucas (2004) opined "Of the tendencies that are harmful to sound economics, the most seductive, and in my opinion, the most poiso-nous is to focus on questions of distribution" (p. 14). 
However, this disdain against inequality is held by a minuscule group of economists. The inequality issue has become a central concern for the majority of economists.

Several reasons for growing inequality have been pointed out such as technology and globalization. Among these, the growth of the financial sector and its dominance over the real sector, called financialization, and its power to influence values and practices of the rest of the society has contributed substantially to growing inequality (Stiglitz, 2015).

The financial sector has moved away from its basic function of allocating capital to productive uses to those activities that are not socially useful. In other words, it has degenerated into rent-seeking activities. According to Stiglitz (2012), rent-seeking is "getting income not as a reward to creating wealth but by grabbing a larger share of the wealth that would otherwise have been produced without their effort" (p. 41). It is also used to describe those activities that are profitable for an individual but serve no useful social function. Rent-seeking also arises from distortion of law and regulation to favor the benefit of special interests, and affect financial market outcomes in their favor. Rent-seeking should be contrasted with value-creating activities. The former subtracts value from society while the later adds value to society (Bogle, 2012). Rent seekers do not create wealth rather, they transfer it from others to themselves.

The financial sector has devised various mechanisms to extract rent. It involves taking advantage of the lack of financial knowledge of customers (asymmetries of information) to design inappropriate products, indulging in excessive risk-taking, using too much leverage and derivatives, and assuming that government will bail them out, or garnering unwarranted profit and remuneration. (Stiglitz, 2012).

\section{Lending against Existing Assets and Alchemy of Finance}

The function of finance is to deploy the savings of households into productive investment. The general trend across countries point out that the bulk of the money is deployed for lending existing assets like homes, stocks, and bonds to convert them into tradable products to be sold many times. It means that the money in the system is not being used to provide funds to new ideas and projects that create jobs and enhance wages, rather it simply circulates inside the financial system (Turner, 2017).

The job of finance has been reduced to alchemy and funneling money into different parts of the financial system. The alchemy leads to the development of new financial products that are several layers away from the real economy. Further, they are so complex that obfuscate and exploit customers to generate rents for financial intermediaries. According to John Kay (2015) "expertise is devoted not to the creation of new assets but to the rearrangement of those that already exist" (p. 178). Hart (1975) demonstrates that there is no solid theoretical justification that financial innovation through expansion of financial opportunities enhances welfare.

\section{The Unbridled Growth of Debt}

Reinhart and Rogoff (2009) consider the inflexibility of debt contracts as the main culprit for financial crises. They note: "if there is one common theme to the vast range of crises . . ., it is that excessive debt accumulation, whether it be by the government, banks, corporations, or consumers....." (p. xxv).

However, the financial system incentivizes the use of debt as interest payments are tax deductible. This nudges the financial system towards debt financing, despite its harmful and disastrous consequences for the economy. The use of debt may be cheaper for individual parties, however, it can have negative externalities which can lead the economy to recession. Admati and Hellwig (2014) state that it is paradoxical as "the tax codes subsidize borrowing, but then capital regulation tries to reduce it. It is as if we provided tax incentives that encouraged reckless driving or pollution while at the same time enacting laws forbidding these behaviors" (p. 226). Mian and Sufi (2015) write that a financial system that relies too much on debt accentuates wealth inequality on account of the uneven distribution of losses in the economy.

The removal of interest tax deduction for debt or limiting it will provide a level playing field for debt and equity and this will decrease the power of the financial sector over the rest of the economy. Pozen (2013) suggests that this can be implemented while lowering the corporate tax rate. This would enable companies to make financing decisions based on economic reasons rather than driven by tax reasons, 
leading to more efficient allocation of resources. However, eliminating tax advantage of debt is stymied by political considerations (Zingales, 2015)

\section{The Bloated Size of the Financial Sector}

The financial sector has become outsized in the USA. Philippon and Reshef (2012) report that much of the increase in financial activity has occurred in speculative fields away from traditional finance. Bolton, Santos, and Scheinkman (2016) argue that a significant portion of these activities are pure rent-seeking and dissipative that entail costs on the rest of the economy.

The advancement of technology should have reduced the intermediation cost. However, according to Philippon (2012), cost of the financial intermediation of the U.S. financial sector was now 2.4 cents on the dollar in 2011 as compared to 1.6 cents at the end of World War II. Phillipon (2012) writes:

Technological improvements in finance have mostly been used to increase secondary market activities, i.e., trading. Trading activities are many times larger than at any time in the previous history. Trading costs have decreased, but I find no evidence that increased liquidity has led to better (i.e., more informative) prices or to more insurance. (p. 236)

Bogle in an interview to Money Magazine (2015) stated that " 99 percent of what we do in this industry is people trading with one another, with a gain only to the middleman. It's a waste of resources". Or simply rent-seeking.

High-frequency trading is advocated to boost liquidity in the market. It uses computer algorithms to exploit arbitrage opportunities at breakneck speed. Budish, Cramton, and Shim (2015) report that the duration of arbitrage opportunities in the Chicago Mercantile Exchange and the New York Stock Exchange diminished from a median of 97 milliseconds in 2005 to seven milliseconds in 2011. Mullainathan (2015) writes:

No doubt that's an achievement, but correcting mispricing at this speed is unlikely to have any real social benefit: What serious investment is being guided by prices at the millisecond level? Shortterm arbitrage, while lucrative, seems to be mainly rent-seeking.
These trading activities serve no useful purpose. Rather, they are designed to outwit the competitor on speed. According to Kay (2015, p. 178), "some of the finest mathematical and scientific minds on the planet are employed to devise algorithms for computerized trading in securities which exploit the weaknesses of other algorithms for computerized trading in securities".

In order to explain the outsized growth of the financial sector, it is pointed out that financial services are similar to health services (Gennaioli, Shleifer, \& Vishny, 2015). As the patients need the advice of doctors for treatment, similarly investors need the services of money doctors: bankers, brokers, wealth planners, or money managers for investment decisions as many investors have a very limited idea of how to invest. However, the analogy of the health sector to account for the outsized growth of the financial sector is not tenable. Zingales (2015) points out that there are many countries that have lower finance GDP ratio yet provide much better health care.

\section{The Shareholders' Revolution}

Jensen and Meckling (1976) in their seminal paper described the agency problem i.e. the potential conflict of interest between shareholders and managers. In order to align interests, it was mooted to link the compensation of managers to firm performance as measured by financial yardsticks such as earnings per share, share prices etc. This has shifted focus to 'shareholder value maximization'. However, the financialized incentives may not be effective as it may lead to a slanted presentation of data through "creative accounting" and even may resort in accounting fraud (Admati, 2017).

Shareholder value maximization tied together two markets: the real market and the expectations market (Martin, 2011). In the real markets, factories are built, products are designed, manufactured, and bought and sold. In the expectation market (stock market), shares of the companies are traded between investors. In the past, professional managers focused on the real market and were compensated for performance in it. Shareholder value maximization has changed this orientation and now they pander more to the expectations market that is subject to the whims of stock markets. This leads to a short-term focus, mismanagement of risk, and harms the long-term viability of companies and does not serve society's broader interest. 


\section{Rising CEO Pay}

The shareholders' revolution has led to the rise of CEO pay. Executive compensation has reached a level that is hard to justify by a rise in productivity or difference in CEO skill sets. The gap between CEO pay and the typical worker has widened from 30:1 to 300:1. These increases have come through squeezing of the workers and investment and have contributed to growing inequality.

Stock options are a significant component of the executive pay that tries to link compensation to the stock value of the company. However, it is an inefficient tool for compensation, as stock prices fluctuate for a variety of reasons not connected with the performance of executives. Further, the value of options can be easily manipulated.

The influence of the CEO on company's performance is also a matter of debate. Fitza (2014) in a comprehensive study of thousands of companies over 1993-2012 estimates that the CEO effect is between $3.9 \%$ and $5 \%$, and a large component of it is attributable to chance. The findings of Fitza have been contested by Quigley and Graffin (2017) on methodological grounds and they estimate the CEO effect to be much larger, which is $21.8 \%$. Fitza (2017) revisits the issue and reaffirms his findings. These findings leave the unanswered question whether CEOs are worth their salary.

The extreme inequality prevalent today in CEO pay and average worker pay is likely to have adverse effects on job satisfaction, employee engagement, team performance, productivity, and trust. According to Payne (2017) "It may inspire workers to slack off, steal, and sabotage" (p. 158). In fact, the deadweight loss of the high salary of the financial sector can be substantial (Philippon \& Reshef, 2012).

\section{Dominance of the Wall Street Culture}

Wall Street culture has come to dominate society and the economy. Volatility and job insecurity characterizes Wall Street. It also intends to make everything liquid or tradeable including jobs and people. It implies that employees are treated as a liability rather than a long-term asset. Wall Street work culture shapes not just the stock market but the rest of the economy. It has penetrated into the workings of non- financial corporations as they have become orientated towards financial thinking. For instance, share buybacks are frequently employed as a corporate strategy to drive stock prices higher. As Foroohar (2016) writes "wealth represented by buybacks stays within a closed loop of the financial markets and the asset portfolios of the richest Americans" (p. 95). This money could have been used to build factories, new ideas, or providing pay hikes to employees. Business schools also contribute to the Wall Street culture as students are taught "how to maximize the tax advantage of debt and how to exploit arbitrage opportunities" (Zingales, 2015, p. 1345).

\section{Regulatory and Cognitive Capture}

Finance holds a disproportionate amount of power in sheer economic terms. This power shapes the mindset of government officials, regulators, CEOs, and even many consumers. This is a sort of "cognitive capture" that influences outcomes, leading to rent extraction. The finance-centric view of the world has become the norm and is rarely questioned in a deep way. The efficient market theory is presented as a gospel of truth to keep the regulation off. This is despite the fact that its empirical evidence is elusive.

\section{Conclusions}

The oversized financial sector has strayed away from its essential function. Several empirical studies document that "too much finance" may hamper growth, create distortions, and contribute to income inequality (Cecchetti \& Kharroubi, 2015; Denk \& Cournède, 2015). Cecchetti and Kharroubi (2015) remark that "the level of financial development is good only up to a point, after which it becomes a drag on growth, and that a fast-growing financial sector is detrimental to aggregate productivity growth" (p. 2).

The financial services industry is mostly performing distributive activity moving wealth from one hand to another. The time, energy, and efforts of the financers are devoted to enriching themselves. DeLong and Cohen (2016) ask "Aside from this finance-led massive redistribution of income to the very top, have the rest of us gotten anything out of this hypertrophy of finance?" (p. 162).

Louis Zingales (2015) in his presidential address remarked 
First of all, [we should] acknowledge that our view of the benefits of finance is inflated. . . . In fact, we have both theoretical reasons and empirical evidence to claim that a component has been pure rent-seeking. By defending all forms of finance, by being unwilling to separate the wheat from the chaff, we have lost credibility in defending the real contribution of finance. (p. 1330)

\section{References}

Admati, A. R. (2017). A Skeptical View of Financialized Corporate Governance. Journal of Economic Perspectives, 31(3), 131-150.

Admati, A., \& Hellwig, M. (2014). The bankers' new clothes: What's wrong with banking and what to do about it. Princeton, NJ: Princeton University Press.

Bogle, J. C. (2012). The clash of the cultures: Investment vs. speculation. Hoboken, NJ: John Wiley \& Sons.

Bogle, J. C. (2015, July 27). Jack Bogle Explains How the Index Fund Won With Investors (P. Regnier, Interviewer). Money Magazine, August 2015. Retrieved from: http://time.com/money/3956351/jack-bogleindex-fund/

Bolton, P., Santos, T., \& Scheinkman, J. A. (2016). Cream-Skimming in Financial Markets. The Journal of Finance, 71(2), 709-736.

Budish, E., Cramton, P., \& Shim, J. (2015). The highfrequency trading arms race: Frequent batch auctions as a market design response. The Quarterly Journal of Economics, 130(4), 1547-1621.

Cecchetti, S. G., \& Kharroubi, E. (2015). Why does financial sector growth crowd out real economic growth? (BIS Working Paper No. 490). Retrieved from: https://www.bis.org/publ/work490.pdf

Cohen, S. S., \& DeLong, J. B. (2016). Concrete Economics: The Hamilton Approach to Economic Growth and Policy. Boston, MA: Harvard Business Review Press.

Denk, O., \& Cournède, B. (2015). Finance and income inequality in OECD countries (OECD Economics Department Working Papers No. 1224). Retrieved from:

http://www.oecd.org/officialdocuments/publicdispla ydocumentpdf/?cote $=\mathrm{ECO} / \mathrm{WKP}(2015) 42 \&$ docLang uage $=$ En

Fitza, M. A. (2014). The use of variance decomposition in the investigation of CEO effects: How large must the CEO effect be to rule out chance? Strategic Management Journal, 35(12), 1839-1852.
Thus, we have to separate the wheat from the chaff. This requires rewriting the rules of the financial sector that has played a major role in exacerbating inequalities in income and wealth.

Fitza, M. A. (2017). How much do CEOs really matter? Reaffirming that the CEO effect is mostly due to chance. Strategic Management Journal, 38(3), 802-811.

Foroohar, R. (2016). Makers and Takers: The Rise of Finance and the Fall of American Business. New York: Crown Books.

Gennaioli, N., Shleifer, A., \& Vishny, R. (2015). Money doctors. The Journal of Finance, 70(1), 91-114.

Gurría, A. (2015, May 21). Launch of "In It Together Why Less Inequality Benefits All". Retrieved from: http://www.oecd.org/employment/publicationlaunch-in-it-together-why-less-inequality-benefitsall.htm

Hart, O. D. (1975). On the optimality of equilibrium when the market structure is incomplete. Journal of Economic theory, 11(3), 418-443.

Jensen, M. C., \& Meckling, W. H. (1976). Theory of the firm: Managerial behavior, agency costs and ownership structure. Journal of Financial Economics, 3(4), 305-360.

Kay, J. (2015). Other People's Money: Masters of the Universe Or Servants of the People? London: Profile Books.

Lucas, R. E. (2004). The Industrial Revolution: Past and Future. Annual Report of the Federal Reserve Bank of Minneapolis. Retrieved from: https://minneapolisfed.org/publications/theregion/the-industrial-revolution-past-and-future

Martin, R. L. (2011). Fixing the game: Bubbles, crashes, and what capitalism can learn from the NFL. Boston, MA: Harvard Business Review Press.

Mian, A., \& Sufi, A. (2015). House of Debt: How they (and you) caused the Great Recession, and how we can prevent it from happening again. Chicago, Il: University of Chicago Press.

Mullainathan, S. (2015, April 10). Why a Harvard Professor Has Mixed Feelings When Students Take Jobs in Finance. The New York Times, The Upshot, Economic View. Retrieved from: https://www.nytimes.com/2015/04/12/upshot/why-a- 
harvard-professor-has-mixed-feelings-whenstudents-take-jobs-in-finance.html

Oxfam International. (2017, January 16). Just 8 men own same wealth as half the world. Retrieved from: https:/www.oxfam.org/en/pressroom/pressreleases/ 2017-01-16/just-8-men-own-same-wealth-halfworld

Payne, K. (2017). The Broken Ladder: How Inequality Changes the Way We Think, Live and Die. London: Hachette UK.

Philippon, T. (2012). Finance vs. Walmart: Why are Financial services so Expensive? In A. Blinder, A. Lo, \& R. Solow (Eds.), Rethinking the Financial Crisis (pp. 235-246). New York: Russell Sage.

Philippon, T., \& Reshef, A. (2012). Wages and human capital in the US finance industry: 1909-2006. The Quarterly Journal of Economics, 127(4), 1551-1609.

Piketty, T. (2013). Capital in the twenty-first century. Cambridge, MA: Harvard University Press.

Pozen, R. (2013, February 18). U.S. Tax reform: Reducing the tax code's bias for debt. Retrieved from: https://www.brookings.edu/opinions/u-s-taxreform-reducing-the-tax-codes-bias-for-debt/

Quigley, T. J., \& Graffin, S. D. (2017). Reaffirming the CEO effect is significant and much larger than chance: A comment on Fitza (2014). Strategic Management Journal, 38(3), 793-801.
Reinhart, C. M., \& Rogoff, K. S. (2009). This time is different: Eight centuries of financial folly. Princeton, NJ: Princeton University Press.

Stiglitz, J. E. (2012). The price of inequality: How today's divided society endangers our future. New York: W. W. Norton \& Company.

Stiglitz, J. E. (2015). Rewriting the rules of the American economy: an agenda for growth and shared prosperity. New York: W. W. Norton \& Company.

Turner, A. (2017). Between debt and the devil: Money, credit, and fixing global finance. Princeton, $\mathrm{NJ}$ : Princeton University Press.

White House Archived [ObamaWhiteHouse]. (2016, September 20). "A world in which $1 \%$ of humanity controls as much wealth as the other $99 \%$ will never be stable" [Tweet]. Retrieved from: https://witter.com/obamawhitehouse/status/7782566 59965616133

World Bank. (2016). Poverty and Shared Prosperity 2016: Taking on Inequality. Washington, DC: World Bank Group.

Zingales, L. (2015). Presidential address: Does finance benefit society? The Journal of Finance, 70(4), 1327-1363.

Valeed Ahmad Ansari is Professor and Dean, Faculty of Management Studies and Research, Aligarh Muslim University, India. He holds an MA in Economics, MBA and a Ph.D. in the area of Finance. His research interests include asset pricing, behavioral finance and Islamic banking and finance. He has published several papers in national journals of repute such as Vikalpa and Margin and in international Journals such as The Journal of Risk Finance, International Journal of Financial Markets and Derivatives and Managerial Finance. He also edited the Islamic Economics Bulletin during1991-94.

E-mail: valeedin@yahoo.com 


\title{
طفيان النشاط المالي وعدم المساواة في الدخل والثروة
}

\author{
وليد أحمد أنصاري \\ جامعة عليجره الإسلامية، الهند
}

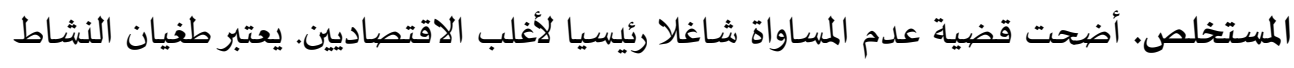

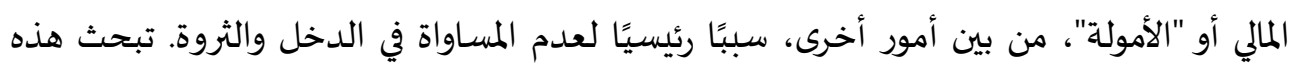

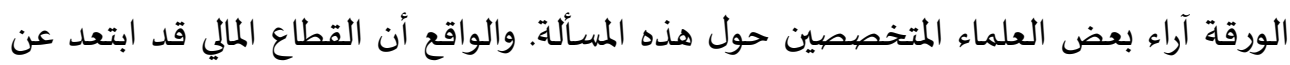

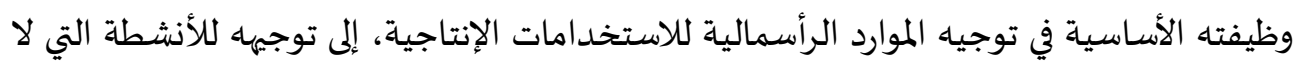

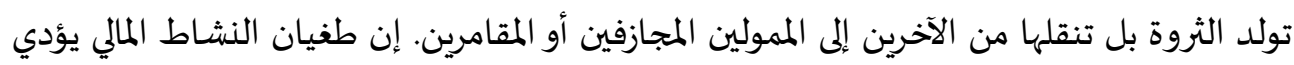

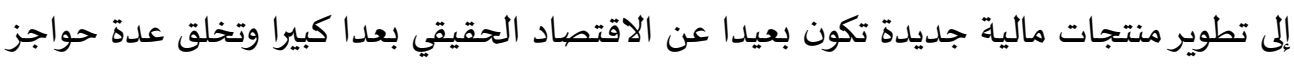

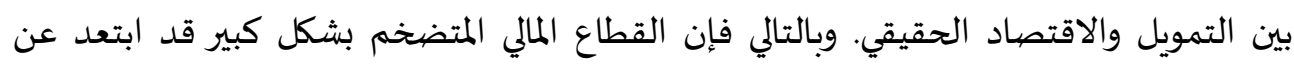

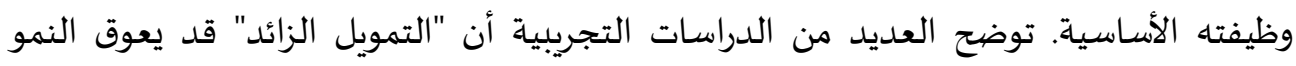
ويخلق التشوهات ويساهم في عدم المساواة في الدخل. 